These results suggest that there is a slight adverse effect when seedlings have more than 25 heat units during the first 5 days after planting. Since the optimum temperature for germination in controlled environments is not obtained with 25 heat units, some other factor is probably responsible for the slight decrease in emergence at heat units above 25

The National Oceanic and Atmospheric Administration (NOAA) provides a weather forecast service. The Bakersfield office has participated the last two years by providing the 5-day heat unit forecast. It is anticipated that other NOAA offices in the San Joaquin Valley will provide the same service in the future. Cotton growers will be able to make sound planting decisions by obtaining warm and cool germination percentage data on seed lots for planting, then refining planting decisions based upon quantifiable weather data.

\section{Conclusions}

If less than 10 heat units are predicted for 5 days, planting would not be recommended. If heat units are predicted to be between 11 and 15, planting should proceed only if germination testing verifies that the seed is of superior quality. If large numbers of acres are to be planted and a grower feels planting must proceed with 11 to 15 heat units, planting rates could be adjusted upward to obtain the desired plant stand. When heat units are predicted to be greater than 16 , conditions are favorable for stand establishment with all but poor-quality seed lots.

Planting rates should be adjusted for the planting conditions and to a lesser extent for the quality of seed (tables 1 and 2 ). Seeding rate changes very little when 16 or more heat units are predicted for 5 days across all ranges of seed quality. When warm plus cool germination percentage is 140 or more, there is also very little adjustment in seeding rate for higher quality planting seed. With 14 or fewer heat units predicted during the 5 days following planting, large adjustments must be made in seeding rates, especially if the seed quality is poor.

Unless growers have no choice, it is recommended that planting seed have at least a warm plus cool germination percentage of 140 . With seeds of lesser quality, plants will take longer to emerge (fig. 1 ), and these seedlings will be exposed to seedling diseases for a longer time. Best yields will be obtained with good-quality seed that can emerge rapidly in an environment promoting fast early growth.

Thomas A. Kerby is Cotton Specialist and Mark Keeley is Staff Research Associate, University of California Cooperative Extension, located at the USDA Cotton Research Station, Shafter, CA 93263; and Cotton Research Station, Shafter, CA 93263; and
Stephanie Johnson is Farm Advisor, Cooperative Extension, Tulare County. The authors gratefully acknowledge the support of this research by a grant from California Planting Cotton Seed Distributors.

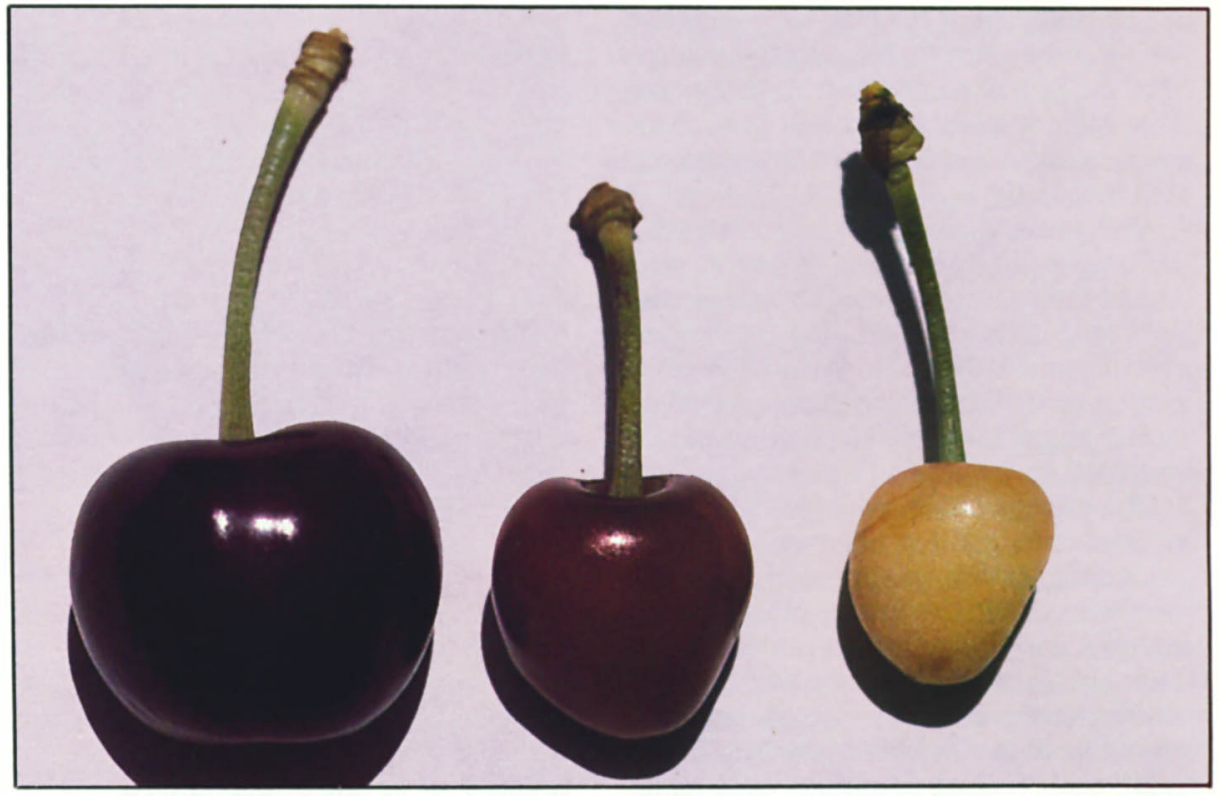

The two cherries at right show typical symptoms of buckskin disease of sweet cherries, named for the pebbly, pale color of diseased fruit. Symptoms may vary, depending on the rootstock and the strain of the disease.

\title{
Buckskin disease of cherry
}

\author{
Alexander H. Purcell $\square$ Jerry K. Uyemoto $\square$ Robert A. Van Steenwyk \\ Wallace R. Schreader $\square$ Karen Gonot Suslow $\square$ Bruce Kirkpatrick
}

$\mathbf{S}$ in California as a result of "cherry decline," a collection of diseases caused by fungi, mycoplasma-like organisms, viruses, and other unidentified agents. A major cause of cherry decline is cherry buckskin disease, also called X-disease of cherry. Buckskin disease was first reported in 1931 on sweet cherry in California and within 20 years eliminated the sweet cherry industry in Napa and Sonoma counties. The disease now threatens cherry production in San Joaquin County.

\section{Symptoms}

The name buckskin disease derives from the pebbly, leathery-skinned, pale fruit of diseased trees. In California, two strains of buckskin, "Napa Valley" and "Green Valley," have been described in sweet cherry. Each strain produces distinct symptoms, depending on the rootstock on which the tree is grafted.

Trees grown on sweet cherry (Prunus avium) 'Mazzard' rootstock and having the Green Valley strain produce smallsized, conical-shaped fruit with short, thick stems. The skin of dark-colored cherry varieties may remain light in color. In addition, leaves on severely diseased trees are smaller, sparser, more yellow, and more erect than normal leaves, giving the tree a "see-through" look. New terminal growth on twigs is usually reduced or absent, and the ends of twigs or branches may die back each year. In contrast, the Napa Valley strain on sweet cherry rootstock induces small, but normal-shaped fruit with normal stem length.

Trees grown on 'Mahaleb' rootstock (P. mahaleb) and having either the Green Valley or the Napa Valley strain may not develop fruit symptoms but instead suddenly wilt and collapse above the graft union. This reaction is thought to be caused by very rapid killing of the rootstock cambium tissues at the graft union when they are contacted by the buckskin disease agent. The rapid death of the cambium tissue prevents the disease agent from spreading into the rootstock. When sweet cherry is grafted high on Mahaleb rootstock on several separate limbs, a single limb may become infected and die without affecting the remainder of the tree. This limb then can be removed and the remainder of the tree reworked.

\section{Cause and spread}

Buckskin appears to be caused by mycoplasma-like organisms found in the nu- 
